\title{
Estimating immediate post-fire carbon fluxes using the eddy- covariance technique
}

\author{
Bruna R. F. Oliveira ${ }^{1}$, Carsten Schaller ${ }^{2}$, J. Jacob Keizer ${ }^{1}$, Thomas Foken ${ }^{3}$ \\ 1 Earth surface processes team, Center for Environmental and Marine Studies (CESAM), \\ Department of Environment and Planning, University of Aveiro, Aveiro, Portugal \\ ${ }^{2}$ Climatology Research Group, Institute of Landscape Ecology, University of Münster, Münster, \\ Germany \\ ${ }^{3}$ Bayreuth Center of Ecology and Environmental Research (BayCEER), University of Bayreuth, \\ Bayreuth, Germany
}

\section{Supplementary material}

\section{Supplementary Tables S1 to S4}

Table S1. Summary of published eddy-covariance studies in woodland areas affected by wildfires 


\begin{tabular}{|c|c|c|c|c|c|c|}
\hline Reference & Location & $\begin{array}{l}\text { Climate } \\
\text { Köppen- } \\
\text { Geiger } \\
\text { system }\end{array}$ & $\begin{array}{l}\text { Dominant } \\
\text { tree species } \\
\text { before } \\
\text { fire/disturbance }\end{array}$ & Stand observations & $\begin{array}{l}\text { Measuring } \\
\text { period }\end{array}$ & NEE $\left[\mathrm{g} \mathrm{C} \mathrm{m}^{-2} \mathrm{y}^{-1}\right]^{*}$ \\
\hline Present study & $\begin{array}{l}\text { Central } \\
\text { Portugal }\end{array}$ & $\mathrm{Csb}$ & Pinus pinaster & Stand replacing fire in Aug2017 & $\begin{array}{l}\text { Oct } 2017- \\
\text { Oct } 2018\end{array}$ & -290 \\
\hline \multirow[t]{6}{*}{ Sun et al. (2016) } & \multirow[t]{6}{*}{ South Australia } & \multirow[t]{6}{*}{ Bsk } & \multirow{6}{*}{$\begin{array}{l}\text { Eucalyptus } \\
\text { dumosa, E } \\
\text { incrassata, E } \\
\text { oleosa, E socialis }\end{array}$} & \multirow[t]{6}{*}{ 1-y after fire May2014-Jul2015 } & May14 & 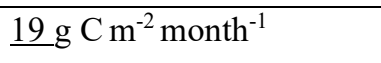 \\
\hline & & & & & Jun14 & $\underline{16} \mathrm{~g} \mathrm{C} \mathrm{m}^{-2} \mathrm{month}^{-1}$ \\
\hline & & & & & Jul14 & $\underline{11} \mathrm{~g} \mathrm{C} \mathrm{m}^{-2} \mathrm{month}^{-1}$ \\
\hline & & & & & May15 & $-18 \mathrm{~g} \mathrm{C} \mathrm{m}^{-2} \mathrm{month}^{-1}$ \\
\hline & & & & & Jun15 & $-13 \mathrm{~g} \mathrm{C} \mathrm{m}^{-2} \mathrm{month}^{-1}$ \\
\hline & & & & & Jul15 & $-12 \mathrm{~g} \mathrm{C} \mathrm{m}^{-2} \mathrm{month}^{-1}$ \\
\hline Dadi et al. (2015) & Cuenca, Spain & $\mathrm{Csb}$ & Pinus nigra & $\begin{array}{l}\text { High severity, stand-replacing fire in July } \\
2009\end{array}$ & $\begin{array}{l}\text { Jun2011- } \\
\text { Feb2013 }\end{array}$ & $\underline{180}$ \\
\hline \multirow[t]{2}{*}{ Serrano-Ortiz et al. (2011) } & \multirow[t]{2}{*}{ SE Spain } & \multirow[t]{2}{*}{ Dsc } & \multirow[t]{2}{*}{ Pinus sylvestris } & \multirow[t]{2}{*}{$\begin{array}{l}\text { Burnt Sept 2005; Salvage logging (SL) vs no } \\
\text { intervention (NI) }\end{array}$} & \multirow[t]{2}{*}{$\begin{array}{l}\text { Jun-Dec } \\
2009\end{array}$} & $\begin{array}{l}\text { BUR-SL } \underline{40} \mathrm{~g} \mathrm{C} \mathrm{m}^{-2} \text { per 7- } \\
\text { months }\end{array}$ \\
\hline & & & & & & $\begin{array}{l}\text { BUR-NI -90 g C m}{ }^{-2} \text { per 7- } \\
\text { months }\end{array}$ \\
\hline \multirow[t]{4}{*}{ Mkhabela et al. (2009) } & \multirow{4}{*}{$\begin{array}{l}\text { Saskatchewan, } \\
\text { Canada }\end{array}$} & \multirow[t]{4}{*}{$\mathrm{Dfb}$} & \multirow[t]{4}{*}{ Pinus banksiana } & BUR 1998 & \multirow{4}{*}{$\begin{array}{l}2004 \text { and } \\
2005\end{array}$} & $\underline{20}$ \\
\hline & & & & BUR 1989 & & -84 \\
\hline & & & & BUR 1977 & & +58 \\
\hline & & & & BUR 1929 & & -20 \\
\hline
\end{tabular}




\begin{tabular}{|c|c|c|c|c|c|c|}
\hline Dore et al. (2008) & Arizona, USA & Csa & Pinus ponderosa & $\begin{array}{l}\text { High severity, stand-replacing fire } 1996 \text { vs } \\
\text { Unburnt }\end{array}$ & $\begin{array}{l}\text { Sep } 2005 \\
\text { to Dec } \\
2006\end{array}$ & $\underline{109 \pm 6}$ \\
\hline \multirow[t]{2}{*}{ Amiro (2001) } & \multirow[t]{2}{*}{ NW Canada } & \multirow[t]{2}{*}{ Dfc } & \multirow[t]{2}{*}{ Pinus banksiana } & $\begin{array}{l}\text { Severely burnt in July 1997; Adjacent UNB } \\
\text { with } 80 \text { years }\end{array}$ & $\begin{array}{l}7-15 \mathrm{Jul} \\
1998\end{array}$ & BUR $\underline{0.8} \mathrm{~g} \mathrm{C} \mathrm{m}^{-2} \mathrm{~d}^{-1}$ \\
\hline & & & & $\begin{array}{l}\text { Burnt } 1989 \text { and aerially seeded in 1990; } \\
\text { Adjacent UNB with } 50 \text { years }\end{array}$ & $\begin{array}{l}10-26 \\
\text { Aug1999 }\end{array}$ & $\begin{array}{l}\mathrm{BUR}=\mathrm{UNB} \\
-1.3 \mathrm{~g} \mathrm{C} \mathrm{m}^{-2} \mathrm{~d}^{-1}\end{array}$ \\
\hline
\end{tabular}

*unless other units indicated 
Table S2. Summary of published eddy-covariance studies in unburnt Pinus pinaster Ait. woodlands

\begin{tabular}{|c|c|c|c|c|c|c|c|}
\hline Reference & Location & Climate & Dominant tree species & Soil & Stand establishment & Tree age $[y]$ & NEP $\left[\mathrm{g} \mathrm{C} \mathrm{m}^{-2} \mathrm{y}^{-1}\right]^{*}$ \\
\hline $\begin{array}{l}\text { Berbigier et al. } \\
(2001)\end{array}$ & $\begin{array}{l}\text { Bordeaux, } \\
\text { France }\end{array}$ & $\mathrm{Cfb}$ & Pinus pinaster Ait & $\begin{array}{l}\text { sandy } \\
\text { hydromorphic } \\
\text { podzol }\end{array}$ & Planted in 1970 & 28 & 575 \\
\hline $\begin{array}{l}\text { Kowalski et al. } \\
(2003)\end{array}$ & $\begin{array}{l}\text { Les Landes, } \\
\text { France }\end{array}$ & $\mathrm{Cfb}$ & Pinus pinaster Ait. & sandy podzol & Clear-felled 50 y old plantation & 1 & -290 \\
\hline \multirow{3}{*}{$\begin{array}{l}\text { Jarosz et al. } \\
(2008)\end{array}$} & \multirow{3}{*}{$\begin{array}{l}\text { Bordeaux, } \\
\text { France }\end{array}$} & \multirow[t]{3}{*}{$\mathrm{Cfb}$} & \multirow[t]{3}{*}{ Pinus pinaster Ait. } & \multirow{3}{*}{$\begin{array}{l}\text { Sandy } \\
\text { hydromorphic } \\
\text { podzol }\end{array}$} & \multirow[t]{3}{*}{ Planted in 1970} & \multirow[t]{3}{*}{32} & 79 total \\
\hline & & & & & & & -59 understory \\
\hline & & & & & & & 138 tree layer \\
\hline \multirow{2}{*}{$\begin{array}{l}\text { Moreaux et al. } \\
\text { (2011) }\end{array}$} & \multirow{2}{*}{$\begin{array}{l}\text { Bordeaus, } \\
\text { France }\end{array}$} & \multirow[t]{2}{*}{$\mathrm{Cfb}$} & \multirow[t]{2}{*}{ Pinus pinaster Ait. } & \multirow[t]{2}{*}{ Sandy podzol } & \multirow{2}{*}{$\begin{array}{l}\text { Clear cut 1999; ploughed and } \\
\text { fertilized 2001; seeded } 2004 \text {. } \\
\text { A: without intervention } \\
\text { B: removal of weed and thinning } \\
\text { of trees in } 2008 / 2009\end{array}$} & A: 4 & 243 \\
\hline & & & & & & B: 5 & 65 \\
\hline $\begin{array}{l}\text { Matteucci et al. } \\
(2015)\end{array}$ & $\begin{array}{l}\text { Tuscany, } \\
\text { Italy }\end{array}$ & $\begin{array}{l}\text { Csa (study } \\
\text { year was } \\
\text { atypically } \\
\text { dry) }\end{array}$ & Pinus pinaster Ait. & $\begin{array}{l}93 \% \text { sand, } \\
3 \% \text { silt; } 4 \% \\
\text { clay. } \\
43.8 \% \text { SOM }\end{array}$ & $\begin{array}{l}\text { Natural regeneration following a } \\
\text { wildfire in } 1944\end{array}$ & 64 & $\begin{array}{l}\text { (May’01-March'02) } \\
21\end{array}$ \\
\hline
\end{tabular}

*unless other units indicated 
Table S3. Summary of the floristic composition on 10 September 2018 as determined by vegetation relevees at the 5 points along the transect in the targeted footprint area

Average and standard

deviation of projected ground

Higher plant species cover (\%)

\begin{tabular}{lc}
\hline Cistus psilosepalus & $23 \pm 18$ \\
Agrostis truncatula & $15 \pm 0$ \\
Cistus ladanifer & $14 \pm 10$ \\
Eucalyptus globulus & $10 \pm 0$ \\
Halimium ocymoides & $7 \pm 5$ \\
Calluna vulgaris & $7 \pm 6$ \\
Pterospartum tridentatum & $7 \pm 2$ \\
Erica spec. & $5 \pm 0$ \\
Arbutus unedo & $5 \pm 0$ \\
Phyllirea angustifolia & $4 \pm 4$ \\
Pinus pinaster & $3 \pm 2$ \\
Lavandula pedunculata & $2 \pm 0$ \\
Genista triachantos & $2 \pm 1$ \\
Conyza bonariensis & $2 \pm 1$ \\
Anarrhinum bellidifolium & $1 \pm 0$ \\
Pteridium aquilinum & $1 \pm 0$ \\
Jasione montana & $1 \pm 0$ \\
Hakea sericea & $1 \pm 0$
\end{tabular}




\section{Supplementary Figures}
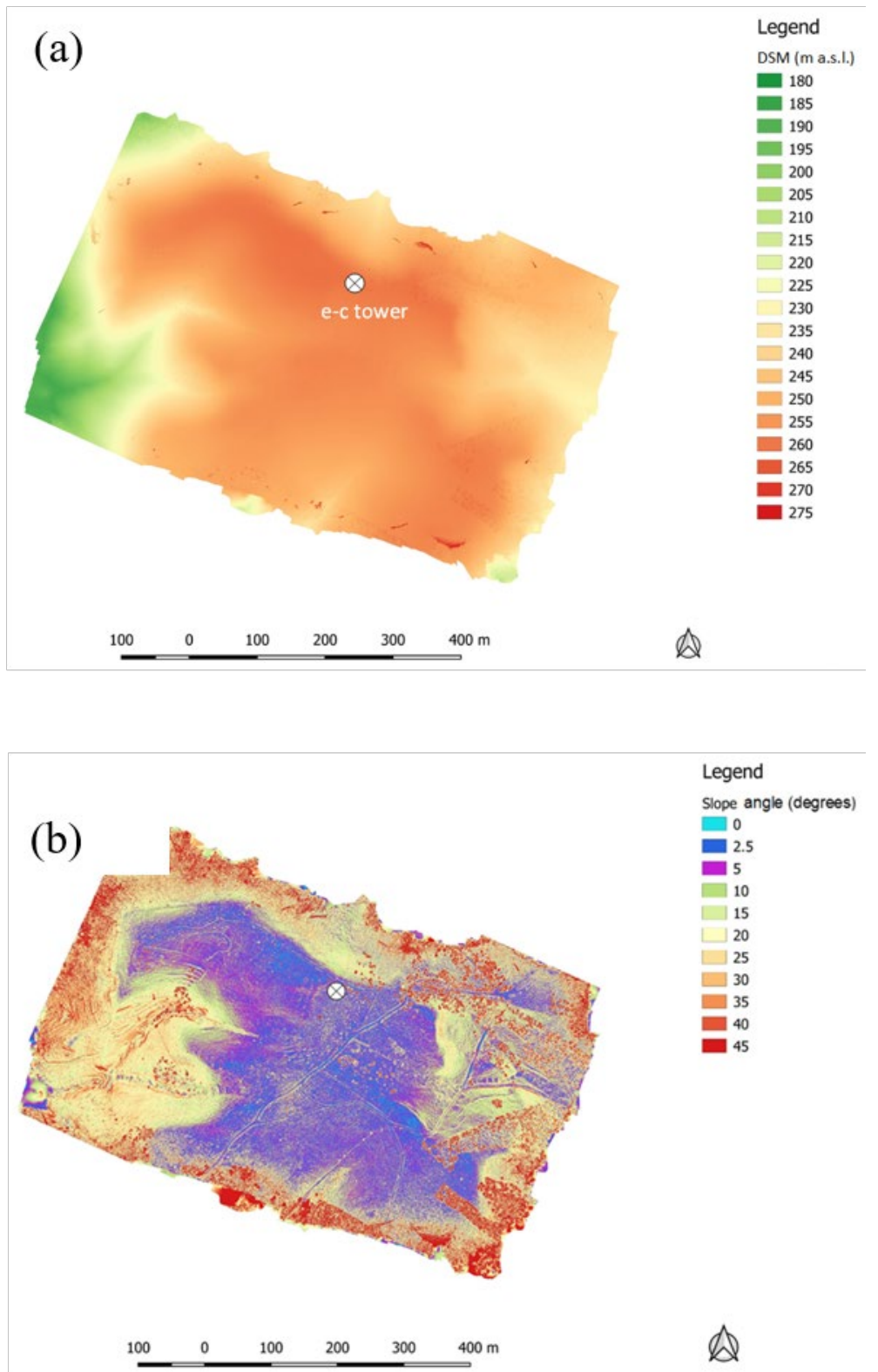

Figure S1. Digital surface model and associated slope angle map derived from aerial photography of the burnt area surrounding the flux tower that was acquired with a RGB camera mounted on a drone (DJI Phantom 3) on 18 July 2017. (tower: circle with cross) 


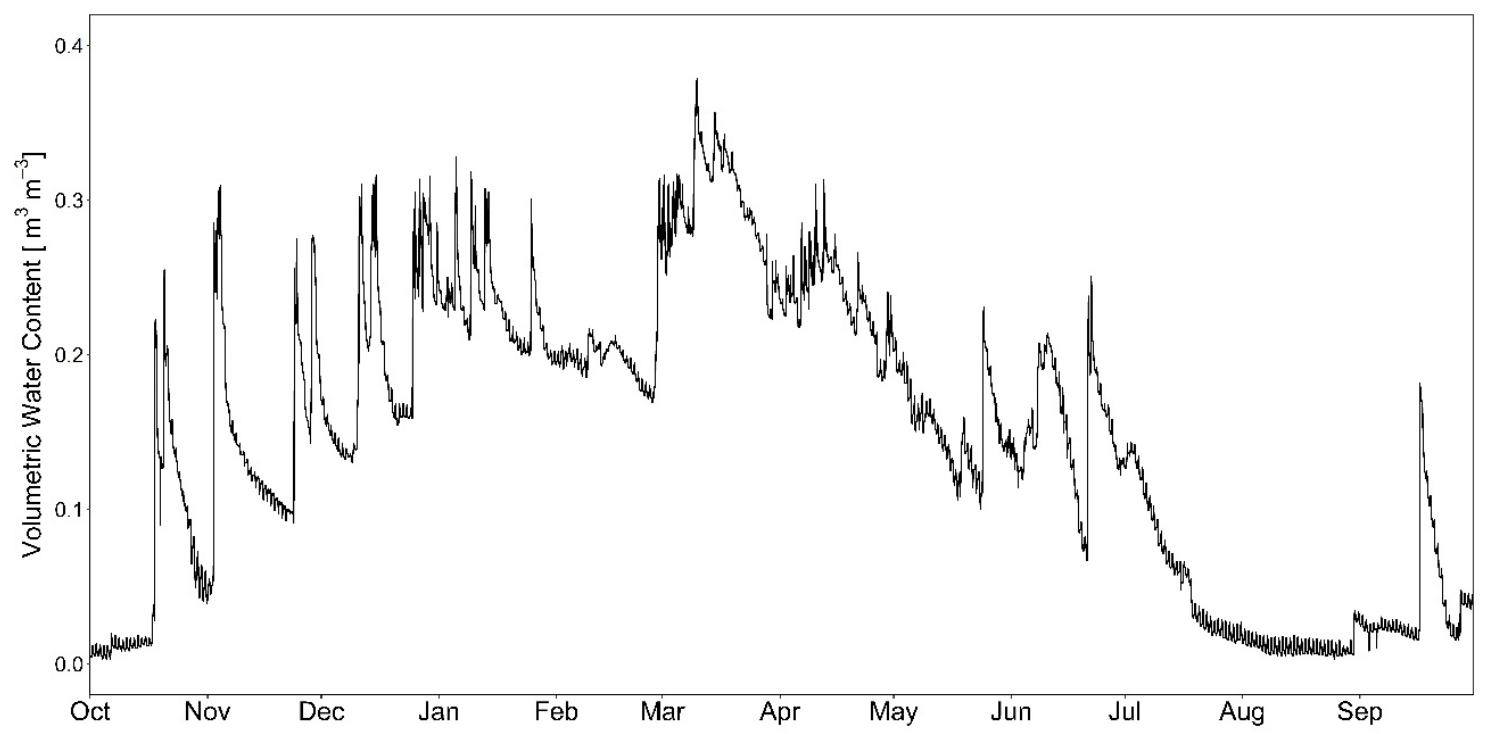

Figure S2. Median 30- minute volumetric soil water content during the 2017/18 hydrological year at $2.5 \mathrm{~cm}$ depth at five inter-patches along a transect laid out to the west of the flux tower in the Maritime pine footprint area.

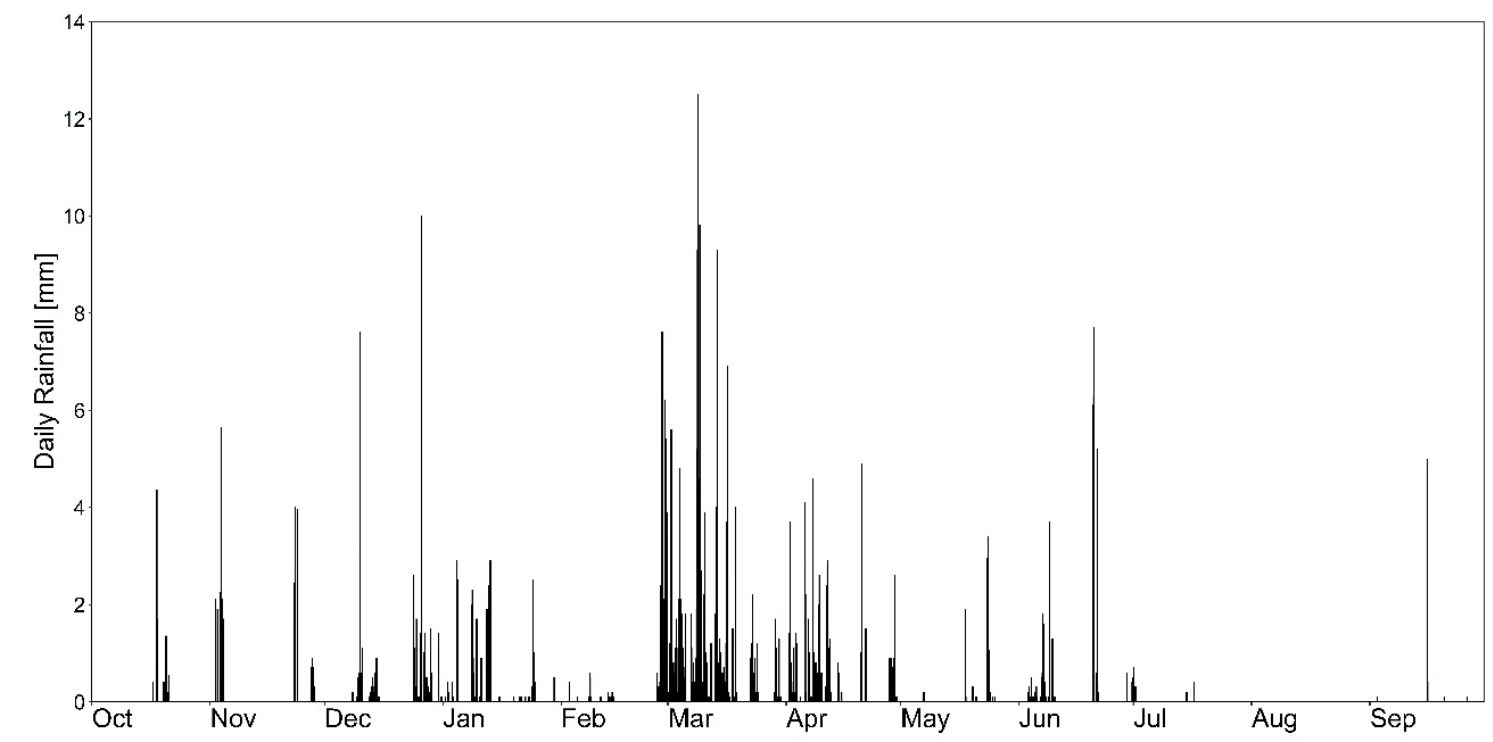

Figure S3: Daily rainfall during the 2017/18 hydrological year as recorded by the automatic gauges installed in the study area. 


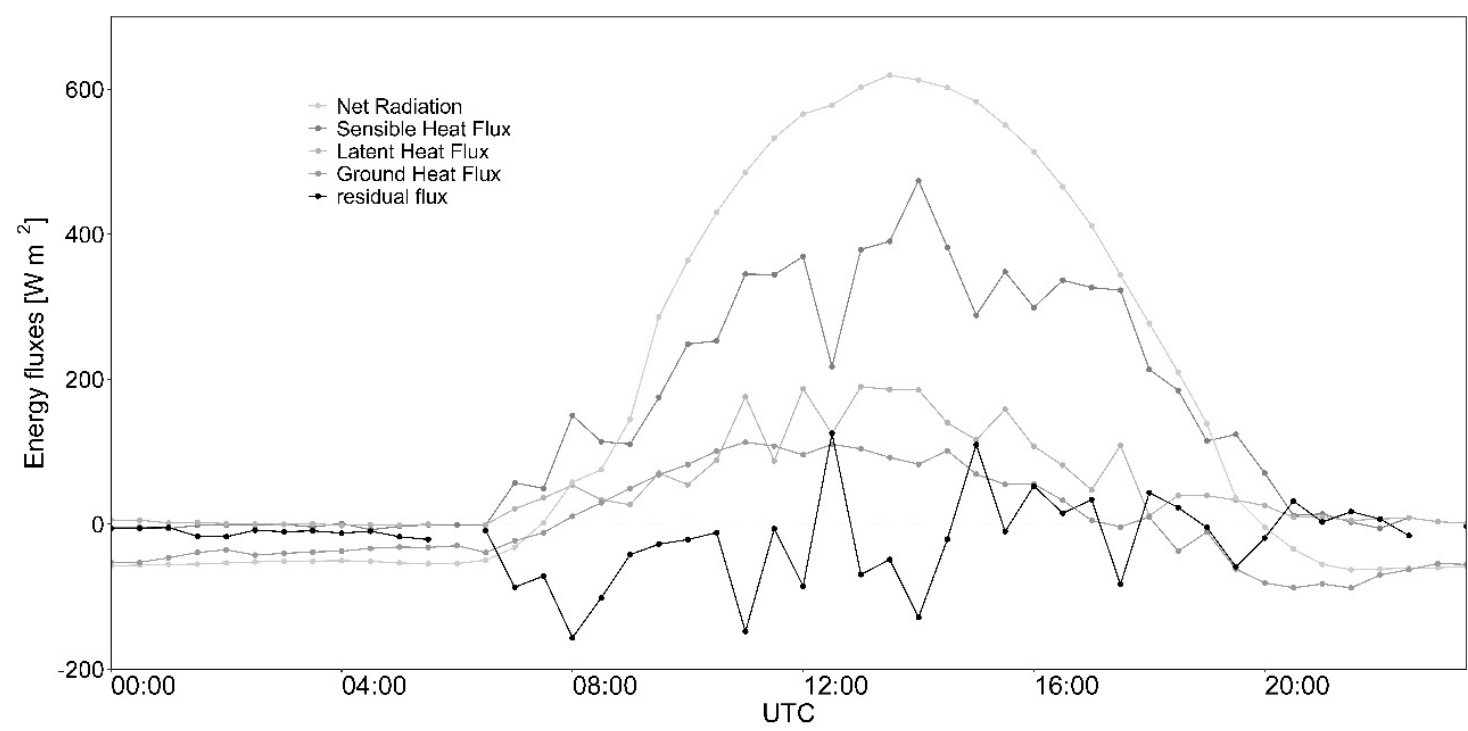

Figure S4. Daily cycle of energy fluxes and their residual on 24 June 2018, when the sky was predominantly clear, except for some high clouds around the local noon at 12:38 UTC. From 08:00 to 19:30 UTC, the footprint consisted for more than $80 \%$ of the Maritime pine woodland.

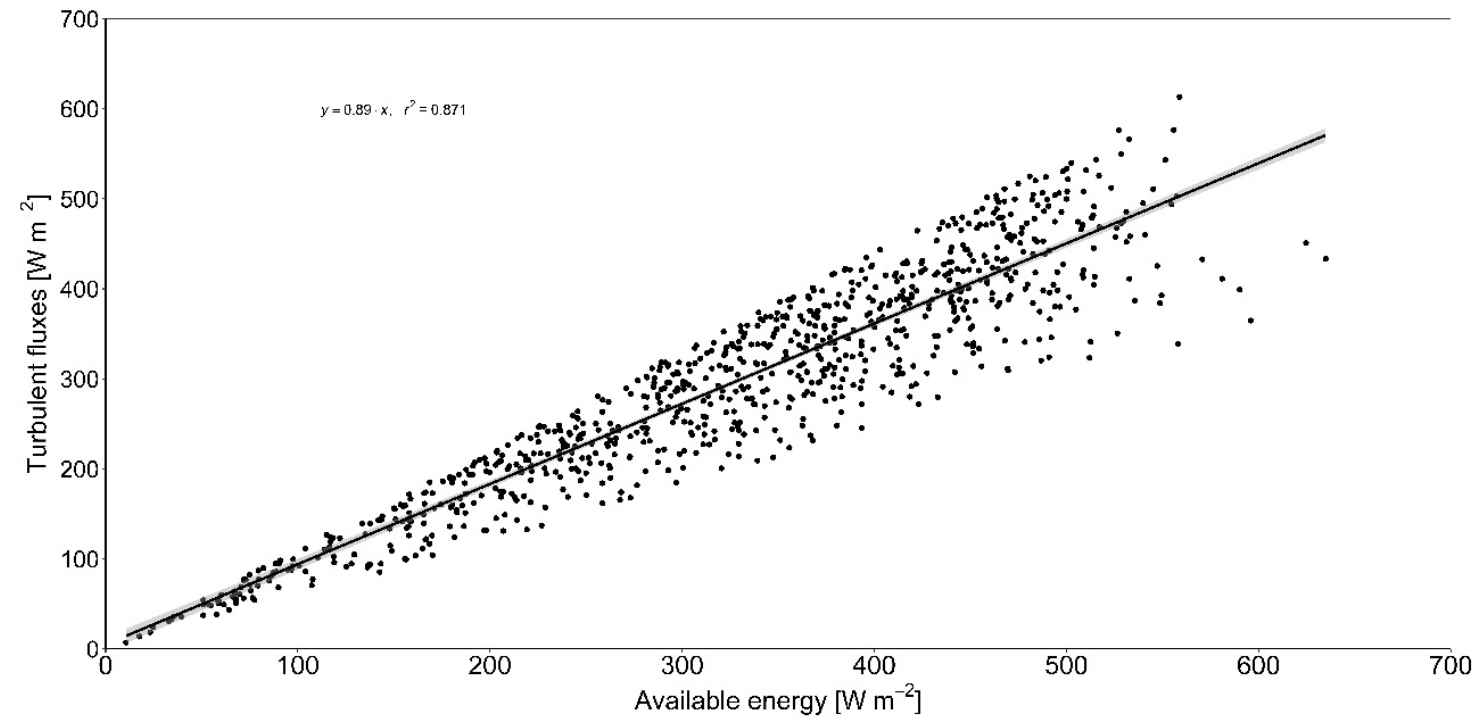

Figure S5. Relationship of turbulent fluxes with available energy for all 30-minute data records that met four conditions: (i) $>\mathbf{8 0} \%$ of the footprint area corresponded to the burnt pine woodland; (ii) the quality flags for the turbulent fluxes ranged from 1 to 6; (iii) sensible and latent heat fluxes were larger than the detection limit of $10 \mathrm{~W} \mathrm{~m}^{-2}$; the ration of latent to sensible heat fluxes passed a MAD-test with $\mathrm{q}=0.5$. 


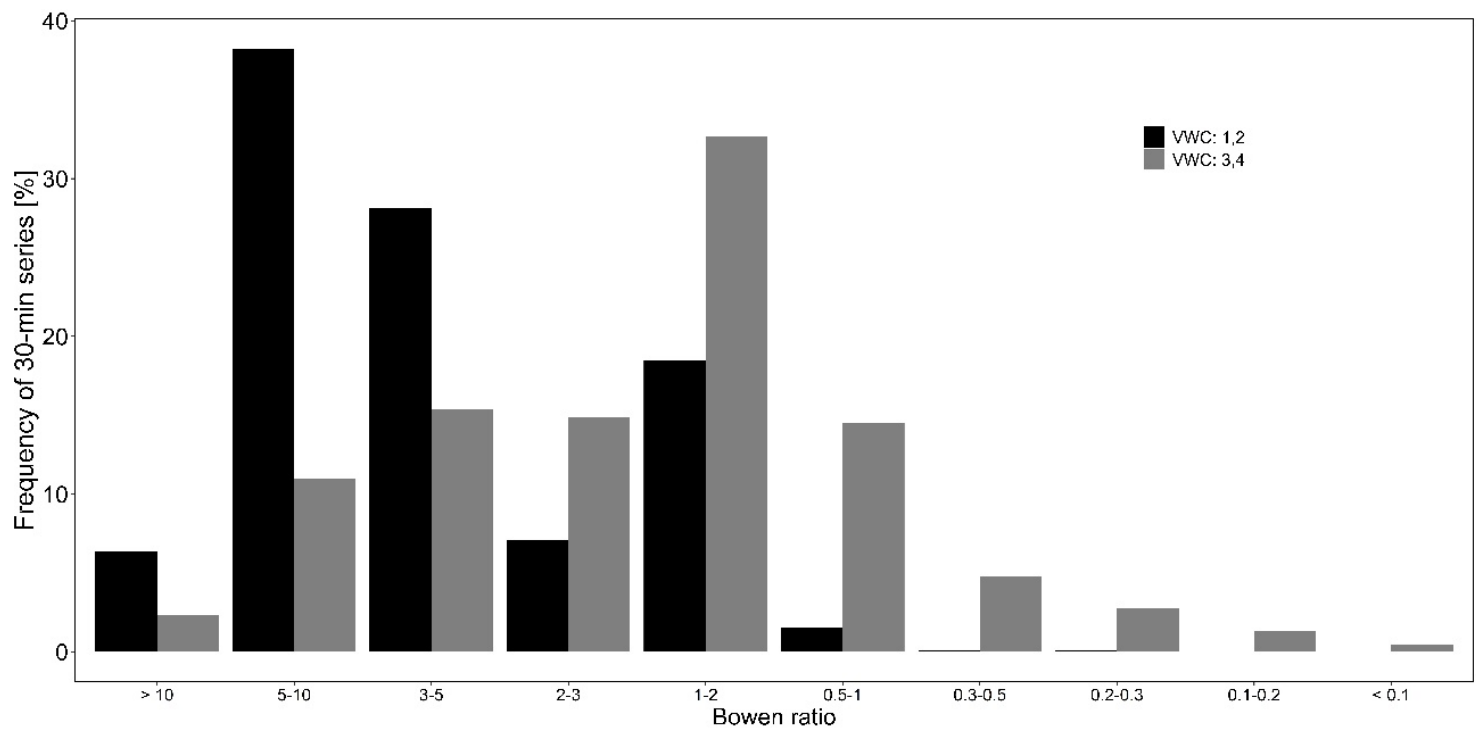

Figure S6. Frequency distribution of the ratio of sensible and latent heat fluxes (Bowen ratio) for two contrasting soil moisture conditions (Volumetric Water Content classes 1 and 2 vs. 3 and 4). The same 30-minute data records as used for Figure S5.

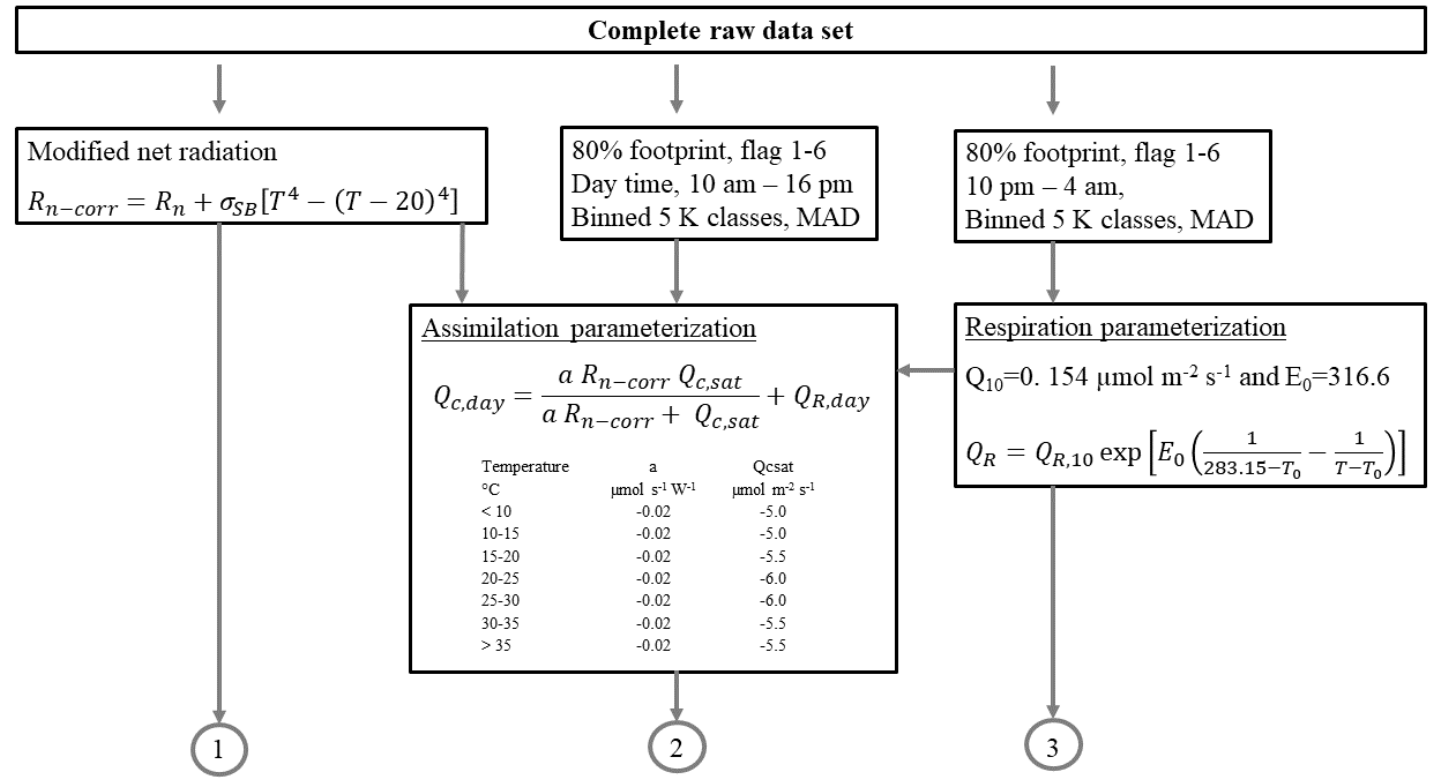

Figure S7. Flow chart of the calculation of the parameters for gap filling of 30-min assimilation and respiration fluxes. 


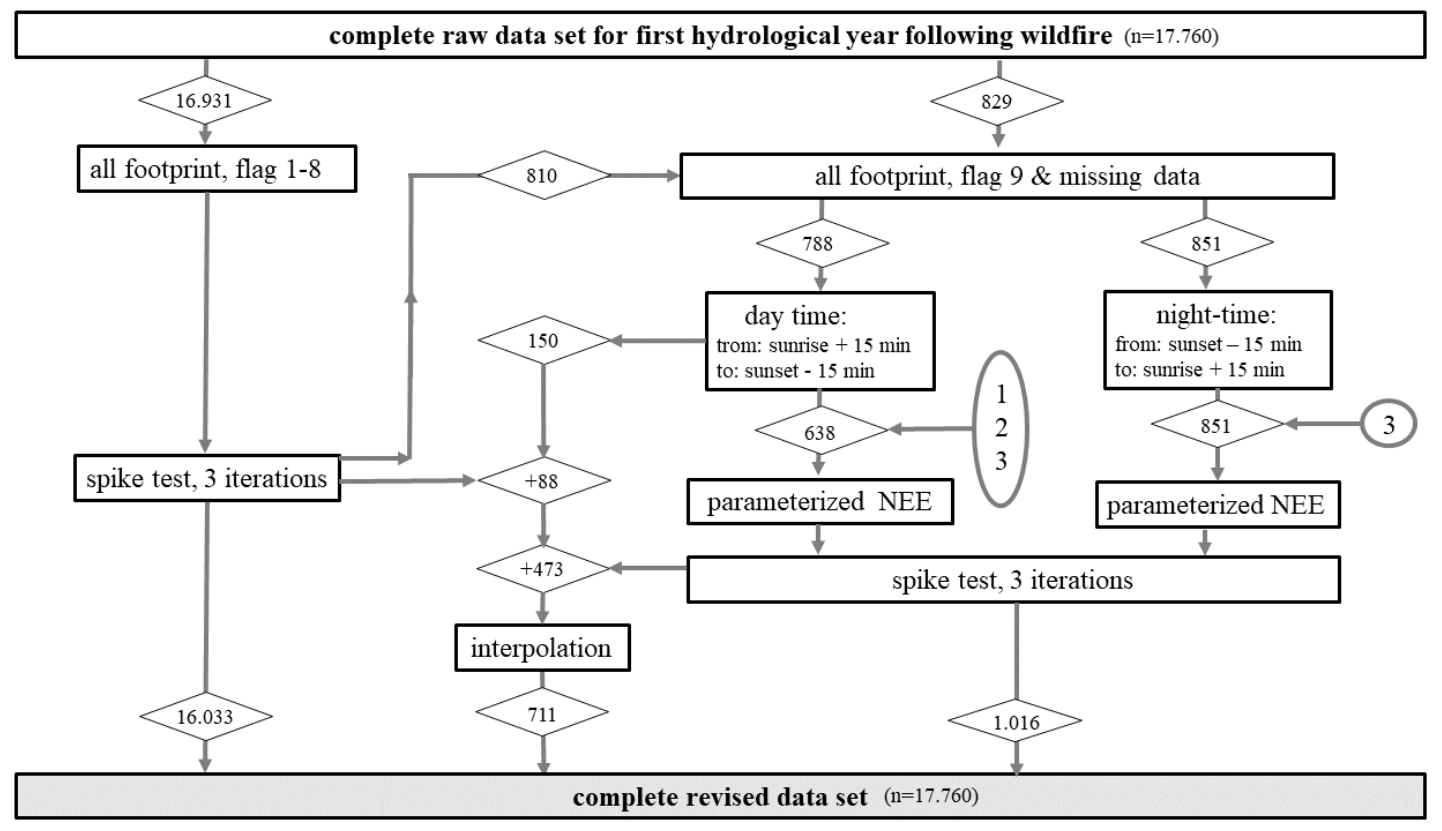

Figure S8. Flow chart of the revision of the raw 30-min data.

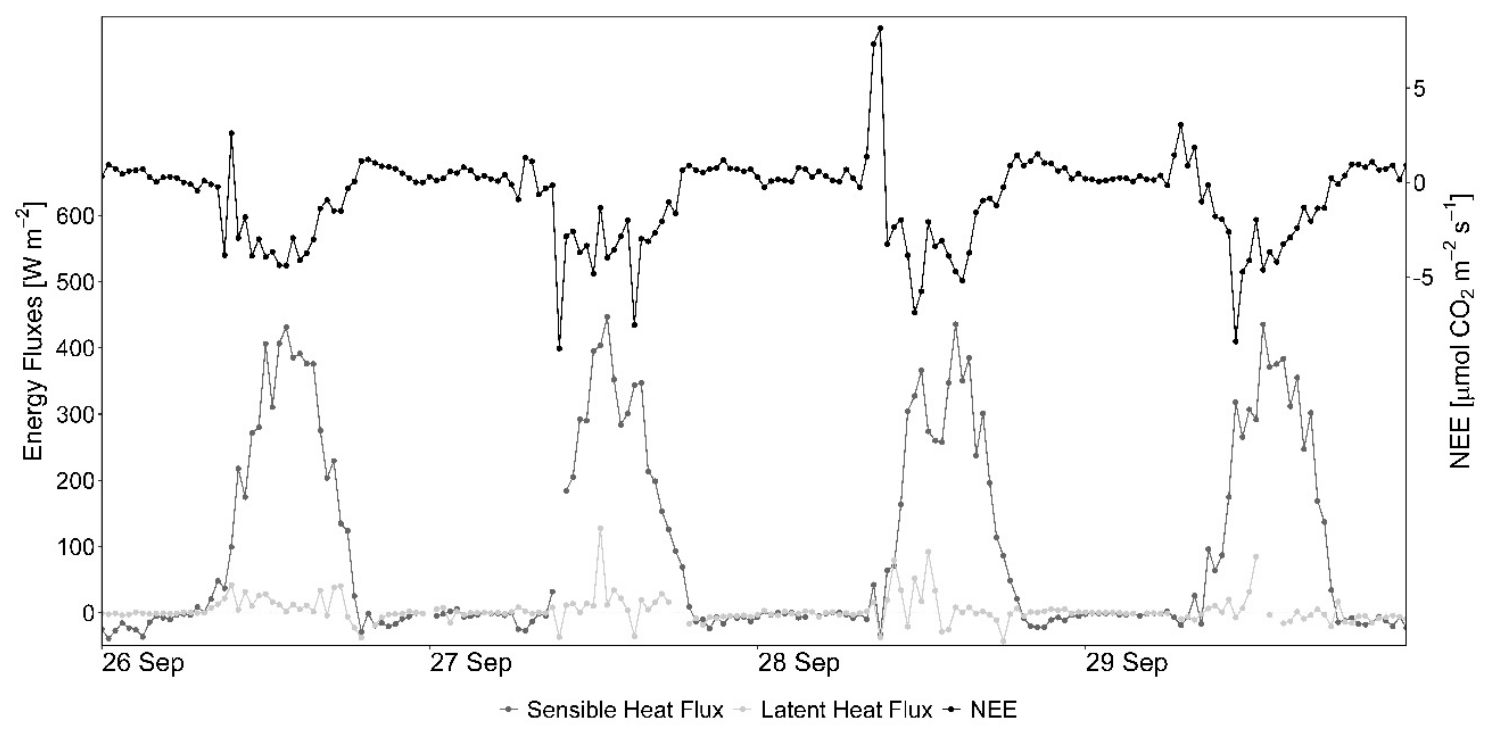

Figure S9. Daily cycles of 30-min sensible and latent heat fluxes and NEE fluxes for the immediate post-fire period from 26 to 29 September 2017. Figure S10 shows the daily cycles of relative humidity together with those of the NEE fluxes. 


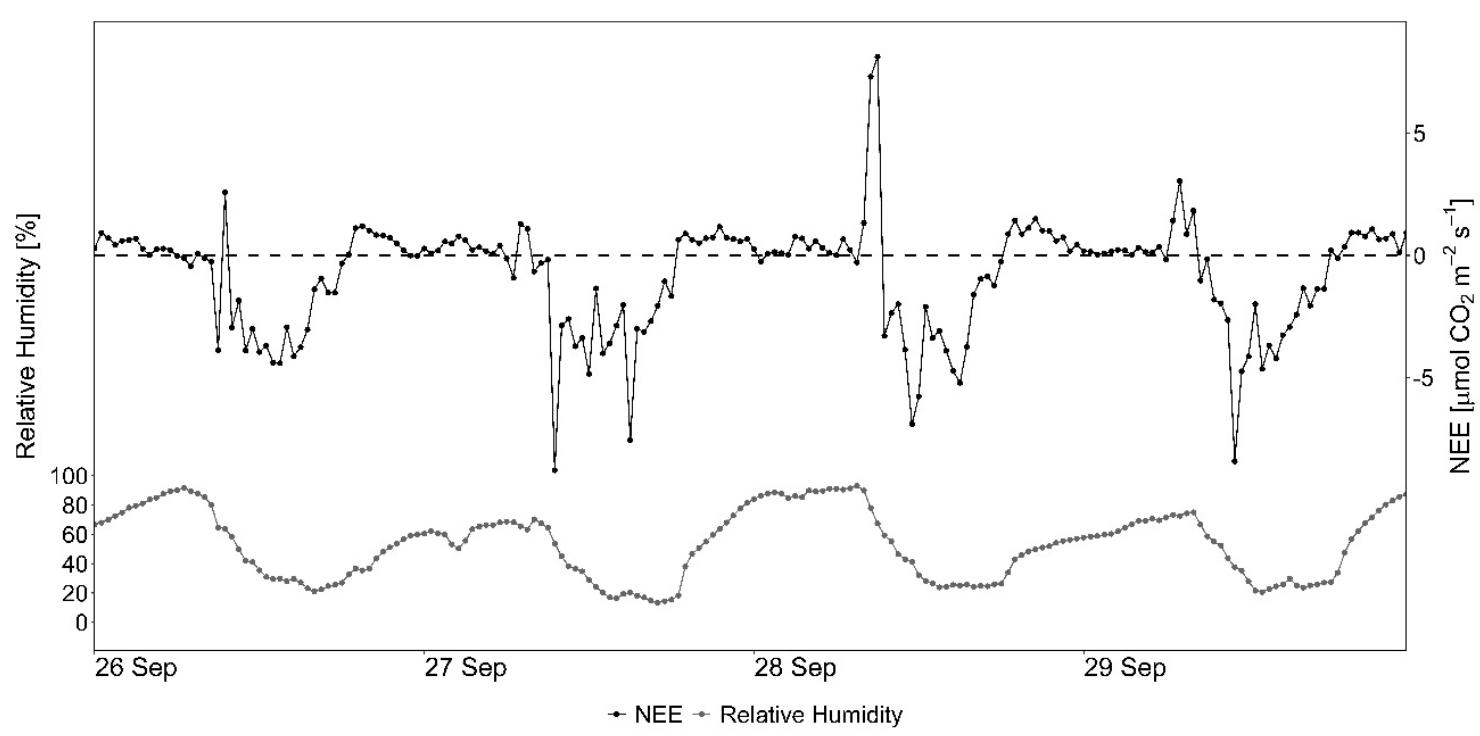

Figure S10. Daily cycles of 30-min relative humidity and NEE fluxes for the immediate post-fire period from 26 to 29 September 2017.

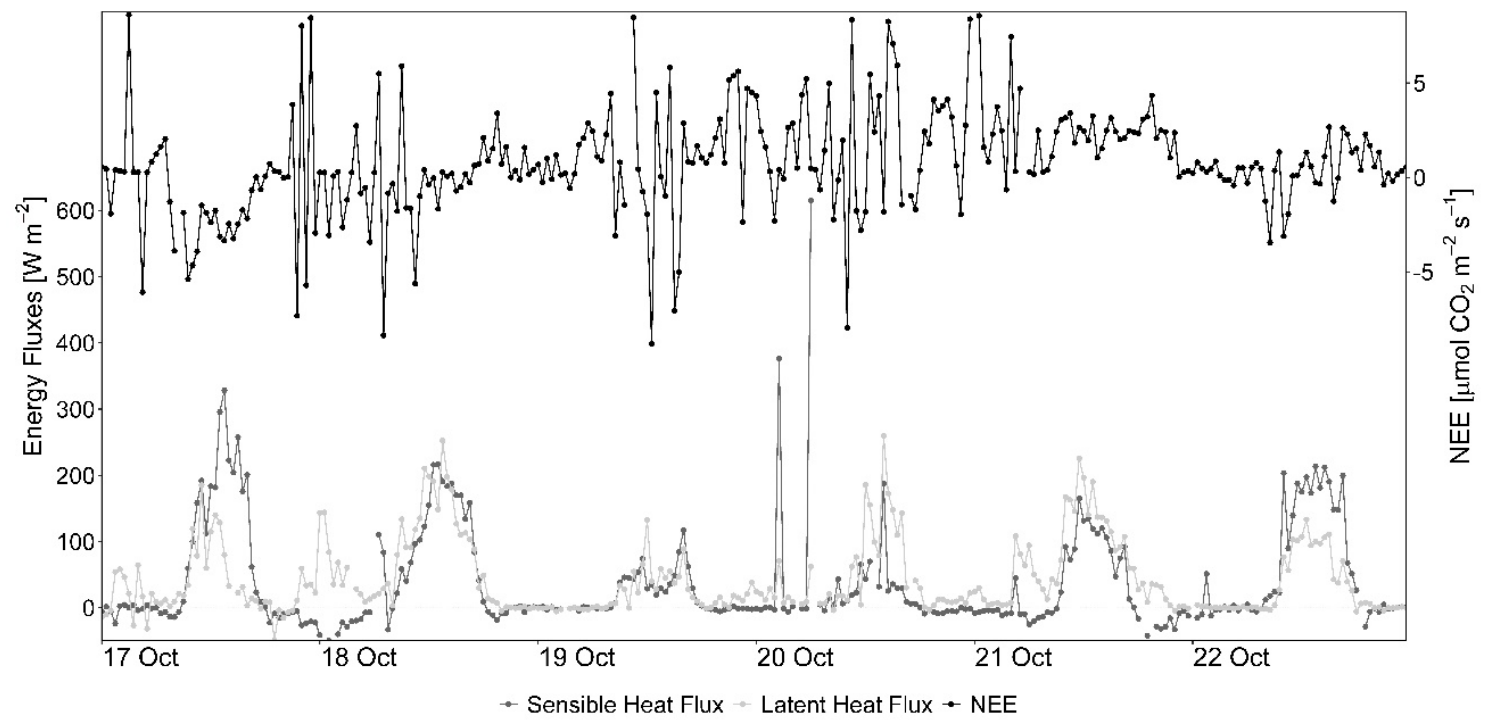

Figure S11. Daily cycles of 30-min sensible and latent heat fluxes and NEE fluxes following the first two significant post-fire rainfall events during the night from 17 to 18 October 2017 and around noon on 20 October 2017. 


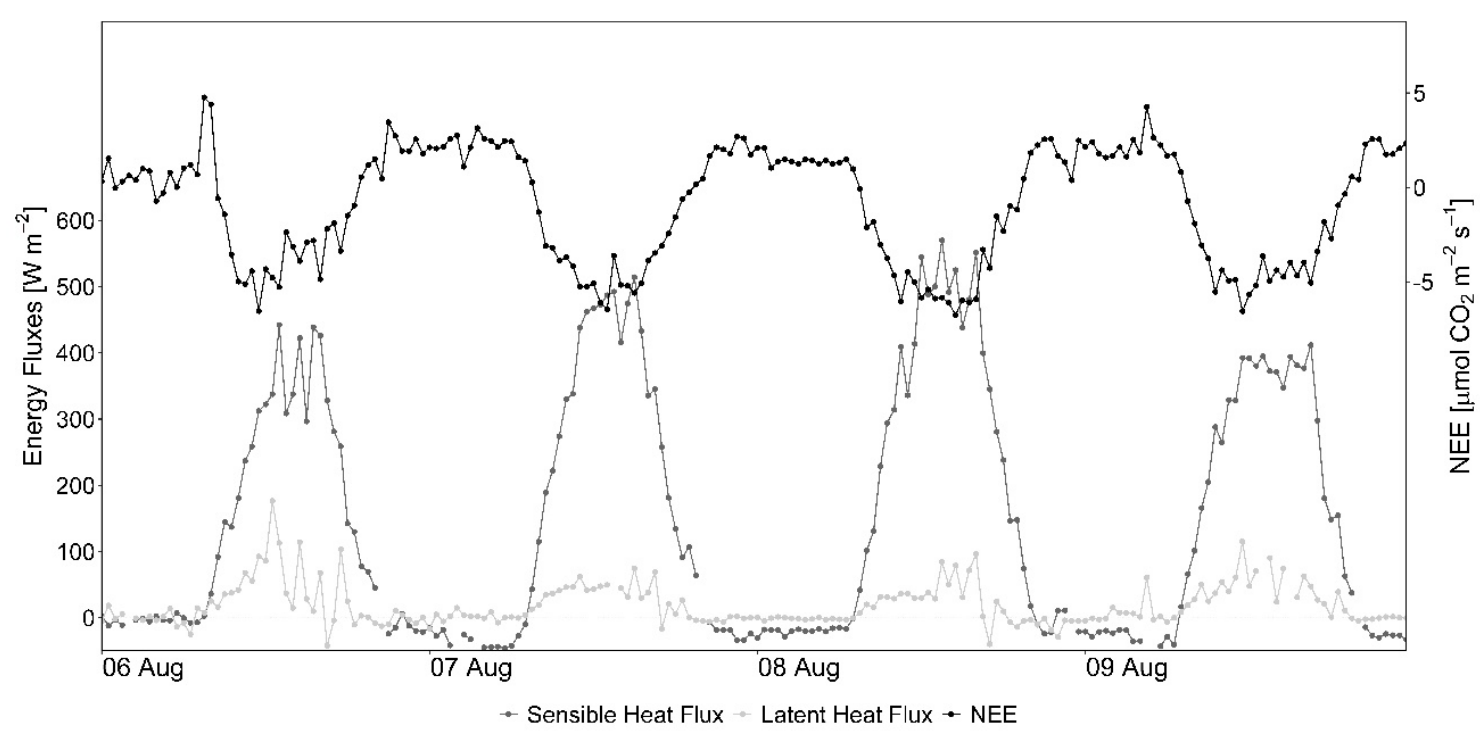

Figure S12. Daily cycles of 30-min sensible and latent heat fluxes and NEE fluxes during mid-summer 2018, from 6 to 9 August, when these fluxes originated from the eucalypt patches.

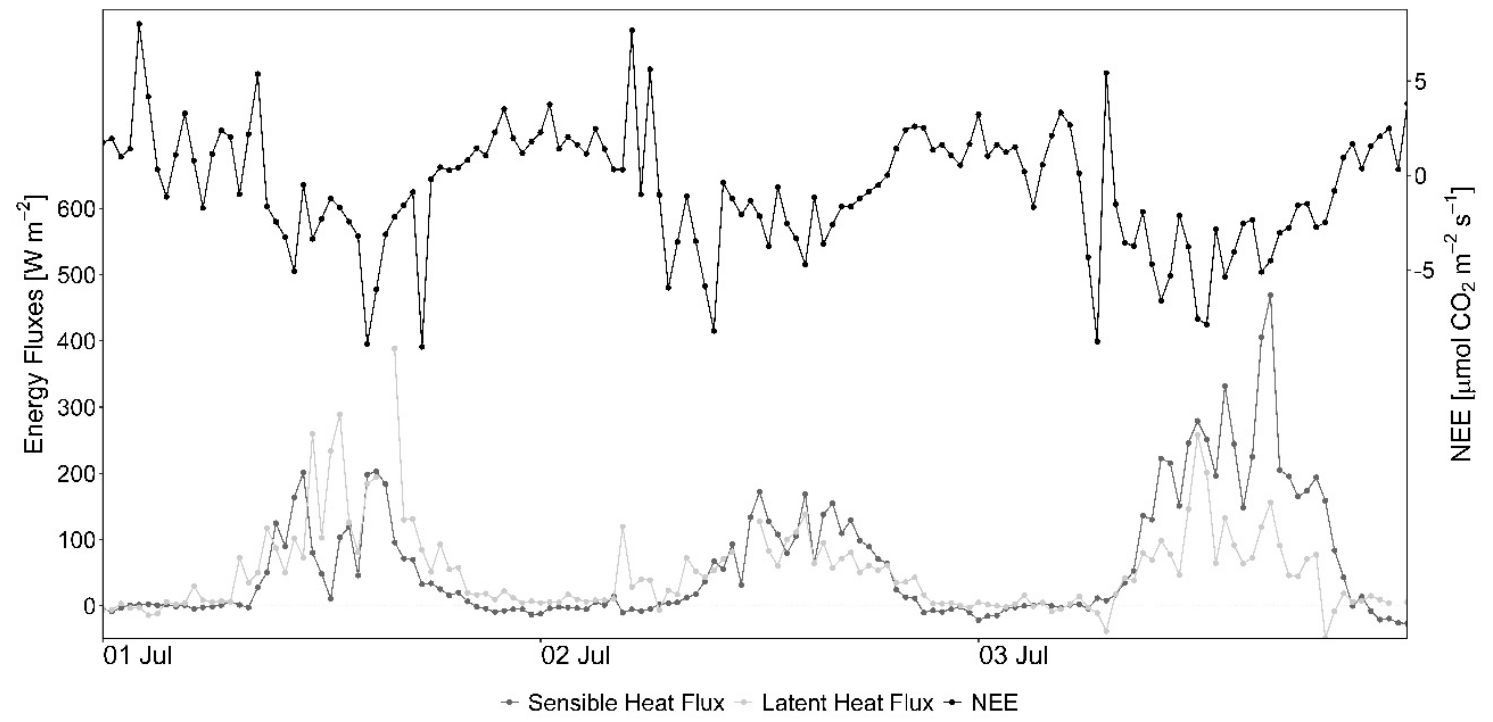

Figure S13. Daily cycles of 30-min sensible and latent heat fluxes and NEE fluxes during early summer 2018, from 1 to 3 July, when these fluxes originated from the Maritime pine woodlands. 

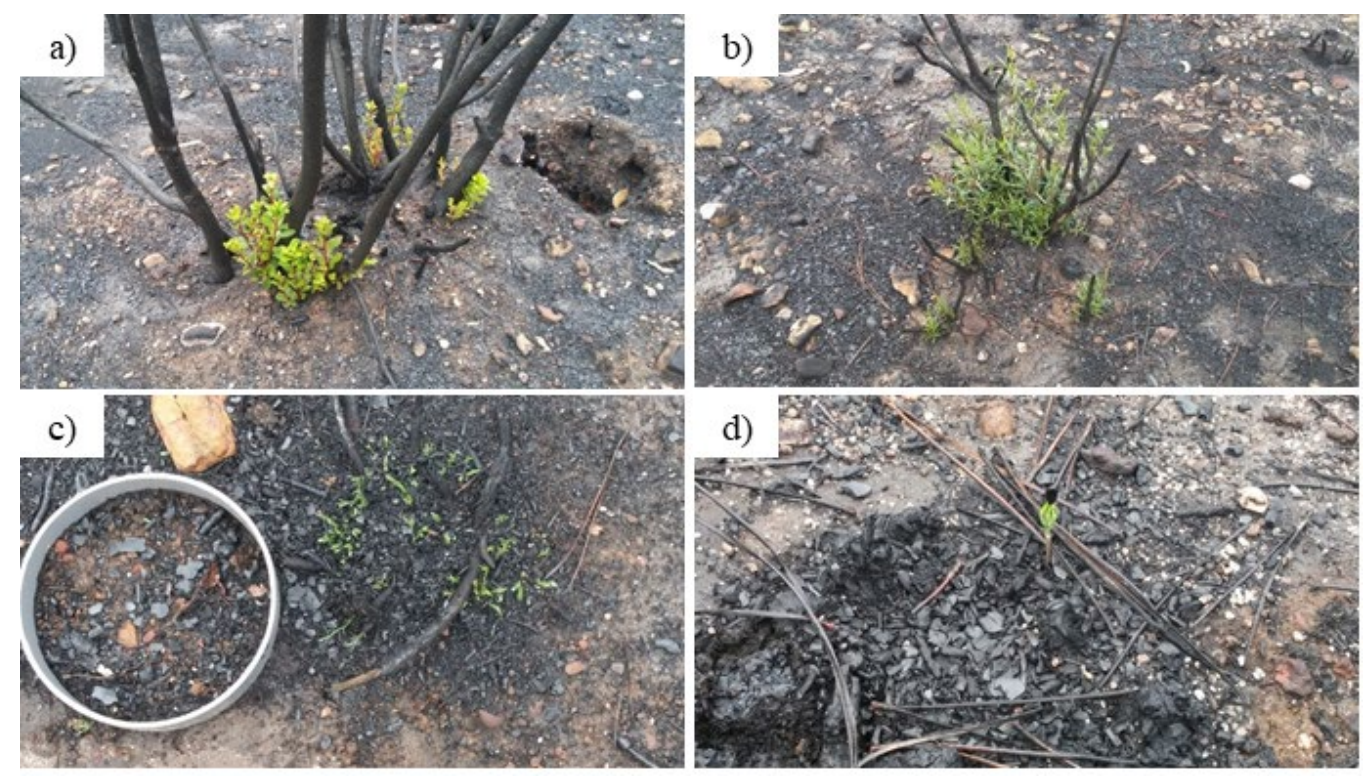

Figure S14. Illustration of post-fire vegetation recovery by 3 January 2018, showing three resprouter shrub species of the understory (a) Arbutus unedo; b) Phillyrea angustifolia; c) Pterospartum tridentatum; and d) Maritime pine seedling. (Pictures by J. Jacob Keizer)

\section{References}

Amiro, B. D.: Paired-tower measurements of carbon and energy fluxes following disturbance in the boreal forest, Glob. Chang. Biol., 7(3), 253-268, doi:10.1046/j.1365-2486.2001.00398.x, 2001.

Berbigier, P., Bonnefond, J.-M. M. and Mellmann, P.: CO2 and water vapour fluxes for 2 years above Euroflux forest site, Agric. For. Meteorol., 108(3), 183-197, doi:10.1016/S01681923(01)00240-4, 2001.

Chan, F. C. C., Altaf Arain, M., Khomik, M., Brodeur, J. J., Peichl, M., Restrepo-Coupe, N., Thorne, R., Beamesderfer, E., McKenzie, S., Xu, B., Croft, H., Pejam, M., Trant, J., Kula, M. and Skubel, R.: Carbon, water and energy exchange dynamics of a young pine plantation forest during the initial fourteen years of growth, For. Ecol. Manage., 410, 12-26, doi:10.1016/J.FORECO.2017.12.024, 2018.

Dadi, T., Rubio, E., Martínez-García, E., López-Serrano, F. R., Andrés-Abellán, M., GarcíaMorote, F. A. and De las Heras, J.: Post-wildfire effects on carbon and water vapour dynamics in a Spanish black pine forest., Environ. Sci. Pollut. Res. Int., 22(7), 4851-62, doi:10.1007/s11356014-3744-4, 2015.

Dore, S., Kolb, T. E., Montes-Helu, M., Sullivan, B. W., Winslow, W. D., Hart, S. C., Kaye, J. P., Koch, G. W. and Hungate, B. A.: Long-term impact of a stand-replacing fire on ecosystem CO2 exchange of a ponderosa pine forest, Glob. Chang. Biol., 14(8), 1801-1820, doi:10.1111/j.1365-2486.2008.01613.x, 2008. 
van Gorsel, E., Berni, J. A. J., Briggs, P., Cabello-Leblic, A., Chasmer, L., Cleugh, H. A., Hacker, J., Hantson, S., Haverd, V., Hughes, D., Hopkinson, C., Keith, H., Kljun, N., Leuning, R., Yebra, M. and Zegelin, S.: Primary and secondary effects of climate variability on net ecosystem carbon exchange in an evergreen Eucalyptus forest, Agric. For. Meteorol., 182-183, 248-256, doi:10.1016/J.AGRFORMET.2013.04.027, 2013.

Jarosz, N., Brunet, Y., Lamaud, E., Irvine, M., Bonnefond, J.-M. and Loustau, D.: Carbon dioxide and energy flux partitioning between the understorey and the overstorey of a maritime pine forest during a year with reduced soil water availability, Agric. For. Meteorol., 148(10), 1508-1523, doi:10.1016/J.AGRFORMET.2008.05.001, 2008.

Kowalski, S., Sartore, M., Burlett, R., Berbigier, P. and Loustau, D.: The annual carbon budget of a French pine forest (Pinus pinaster) following harvest, Glob. Chang. Biol., 9(7), 1051-1065, doi:10.1046/j.1365-2486.2003.00627.x, 2003.

Kulmala, L., Pumpanen, J., Kolari, P., Dengel, S., Berninger, F., Köster, K., Matkala, L., Vanhatalo, A., Vesala, T. and Bäck, J.: Inter- and intra-annual dynamics of photosynthesis differ between forest floor vegetation and tree canopy in a subarctic Scots pine stand, Agric. For. Meteorol., 271, 1-11, doi:10.1016/J.AGRFORMET.2019.02.029, 2019.

Matteucci, M., Gruening, C., Goded Ballarin, I., Seufert, G. and Cescatti, A.: Components, drivers and temporal dynamics of ecosystem respiration in a Mediterranean pine forest, Soil Biol. Biochem., 88, 224-235, doi:10.1016/j.soilbio.2015.05.017, 2015.

Mkhabela, M. S., Amiro, B. D., Barr, A. G., Black, T. A., Hawthorne, I., Kidston, J., McCaughey, J. H., Orchansky, A. L., Nesic, Z., Sass, A., Shashkov, A. and Zha, T.: Comparison of carbon dynamics and water use efficiency following fire and harvesting in Canadian boreal forests, Agric. For. Meteorol., 149(5), 783-794, doi:10.1016/j.agrformet.2008.10.025, 2009.

Moreaux, V., Lamaud, É., Bosc, A., Bonnefond, J. M., Medlyn, B. E. and Loustau, D.: Paired comparison of water, energy and carbon exchanges over two young maritime pine stands (Pinus pinaster Ait.): Effects of thinning and weeding in the early stage of tree growth, Tree Physiol., 31(9), 903-921, doi:10.1093/treephys/tpr048, 2011.

Peichl, M., Brodeur, J. J., Khomik, M. and Arain, M. A.: Biometric and eddy-covariance based estimates of carbon fluxes in an age-sequence of temperate pine forests, Agric. For. Meteorol., 150(7-8), 952-965, doi:10.1016/J.AGRFORMET.2010.03.002, 2010.

Rodrigues, A., Pita, G., Mateus, J., Kurz-Besson, C., Casquilho, M., Cerasoli, S., Gomes, A. and Pereira, J.: Eight years of continuous carbon fluxes measurements in a Portuguese eucalypt stand under two main events: Drought and felling, Agric. For. Meteorol., 151(4), 493-507, 
doi:10.1016/J.AGRFORMET.2010.12.007, 2011.

Serrano-Ortiz, P., Marañón-Jiménez, S., Reverter, B. R., Sánchez-Cañete, E. P., Castro, J., Zamora, R. and Kowalski, A. S.: Post-fire salvage logging reduces carbon sequestration in Mediterranean coniferous forest, For. Ecol. Manage., 262(12), 2287-2296, doi:10.1016/j.foreco.2011.08.023, 2011.

Sun, Q., Meyer, W. S., Koerber, G. R. and Marschner, P.: A wildfire event influences ecosystem carbon fluxes but not soil respiration in a semi-arid woodland, Agric. For. Meteorol., 226-227, 57-66, doi:10.1016/j.agrformet.2016.05.019, 2016. 